\title{
Infection of terrestial snails with larvae of Elaphostrongylus cervi (Nematoda, Protostrongylidae) in Białowieża National Park
}

\author{
I. KULIGOWSKA, A. W. DEMIASZKIEWICZ
} W. Stefański Institute of Parasitology, Polish Academy of Sciences, ul. Twarda 51/55, 00-818 Warszawa, Poland,
E-mail: kuligowska@twarda.pan.pl

\begin{abstract}
Summary
Species composition of intermediate hosts of Elaphostrongylus cervi - terrestrial snails, prevalence and intensity of their infection in natural invasions have been determined. The intermediate hosts of E. cervi are Succinea putris, Bradybena fruticum, Perforatella bidentata and Zonitoides nitidus. From June to August the percentage of snails $S$. putris infected with $E$. cervi larvae has been on constant level and in September and October decreased. Snails $B$. fruticum the highest prevalence of invasion showed on July and later it successively lowered. In the case of P. bidentata prevalence of $E$. cervi infection was the lowest in August, and than raised up to the highest value in October. For the first time the highest extensiveness of spontaneous infection has been found in P. bidentata. Till now as the most infected species of snail always has been noted $S$. putris. The highest intensity of infection - 242 larvae was found in B. fruticum, and little lower - 202 in S. putris. In two other species intensiveness ranged from 1 to 23 larvae. The most important role in spreading of $E$. cervi in Białowieża Forest fulfil $S$. putris and B. fruticum because of their high number in environment and $P$. bidens because of the highest intensiveness of infection.
\end{abstract}

Keywords: Elaphostrongylus cervi; Cervides; Protostrongylidae; Nematodes; intermediate host

\section{Introduction}

Elaphostrongylus cervi Cameron, 1931 is the nematode from the family Protostrongylidae, parasite of intermuscular connective tissue and central nervous system. This parasite occurres in red deer in Eurasia. Adult nematodes situated in the intermuscular connective tissue cause subclinical elaphostrongylosis, while those occurring in the central nervous system may produce grave clinical symptoms leading even to death of the deer. Many species of terrestrial snails can play the role of their intermediate hosts. In the external environment $\mathrm{L}_{\mathrm{I}}$ get out feaces of a deer and actively penetrate body integument of a snail. In the muscles of foot $\mathrm{L}_{\mathrm{I}}$ feed themselves intensively, grow up, molt twice and in the period of 20 - 40 days reach invasive stadium $\mathrm{L}_{\text {III }}$ (Demiaszkiewicz, 1987b). Red deer infect themselves with these nematodes eating together with grass and vegetable creeping on them infected with invasive larvae small terrestrial snails.

\section{Material and methods}

Snails were collected in section No 314 in centrum of restricted part of Białowieża National Park Natural Reserve, along Orłówka river, in red deer watering place.

Table 1. Results of snails collecting in $2000-2004$ year

\begin{tabular}{lccccc}
\hline Snails & $\mathbf{2 0 0 0}$ & $\mathbf{2 0 0 1}$ & $\mathbf{2 0 0 2}$ & $\mathbf{2 0 0 3}$ & $\mathbf{2 0 0 4}$ \\
\hline Succinea putris & 257 & 1393 & 158 & 327 & 105 \\
Bradybaena fruticum & 97 & 433 & 24 & 277 & 162 \\
Perforatella bidens & 17 & 87 & 21 & 38 & 3 \\
Zonitoides nitidus & 2 & 41 & 46 & 2 & 6 \\
Valonia costata & & & & & 26 \\
Cochlicopa lubrica & & & & 6 & 15 \\
Limax sp. & & & & & 9 \\
Arion subfuscus & & 7 & & & 1 \\
Clausilia pumila & & & & & 3 \\
Laciniaria sp & & & 3 & & \\
Limax cinereo-niger & & 1 & 1 & & \\
Trichia hispida & & 2 & & & \\
Vitrina pellucida & & 2 & & & \\
\hline total & $\mathbf{3 7 3}$ & $\mathbf{1 9 6 6}$ & $\mathbf{2 5 3}$ & $\mathbf{6 5 0}$ & $\mathbf{3 3 0}$ \\
\hline
\end{tabular}


Snails were collected on the surface and $10 \mathrm{~cm}$ deep early morning with dew, when the snails were active. Results of snails collecting are presented in Tab.1.

To examine the infection of the snails by larvae of $E$. cervi, snails were necropsied and examined in compressor using stereomicroscope with 40x magnification. After fragmentation snails were digested in $1 \%$ pepsin in 1 molar hydrochloric acid to compare with results from compressor examination.

Table 2. Infection of snails with larvae of Elaphostrongylus cervi in Białowieża National Park in 2000

\begin{tabular}{ccccc}
\hline Snails & Examined & Infected & \% & Intensity \\
\hline $\begin{array}{c}\text { Succinea } \\
\text { putris } \\
\text { Perforatella } \\
\text { bidentata }\end{array}$ & 257 & 12 & 4.6 & $1-12$ \\
$\begin{array}{c}\text { Bradybaena } \\
\text { fruticum }\end{array}$ & 97 & 3 & 3.08 & $4-9$ \\
$\begin{array}{c}\text { Zonitoides } \\
\text { nitidus }\end{array}$ & 2 & - & - & - \\
\hline total & $\mathbf{3 7 3}$ & $\mathbf{1 6}$ & $\mathbf{4 . 2 9}$ & \\
\hline
\end{tabular}

\section{Results}

All results of infection of particular species of snails in successive years are presented in tables No. $2-8$.

During the period 2000 - 2004 in Białowieża National Park were collected 3572 terrestrial snails belonging to 13 species. The most numerous species was $S$. putris. Also common species were $B$. fruticum, $P$. bidentata and $Z$. nitidus. Other species occurred incidentally and only some specimens have been collected. Among 13 examined species $E$. cervi was found in 4 of them but the prevalence of invasion varied. The most infected snail in all examined periods was $P$. bidentata $-12.04 \%$, and in 2001 prevalence of invasion in it was also the highest and reached $20.6 \%$. Prevalence of infection of the other species with larvae of E. cervi was lower and extended in S. putris 8.7 $\%$, Z. nitidus $6.2 \%$, and B. fruticum $4.2 \%$. In 2001

Table 3. Infection of snails with larvae of Elaphostrongylus cervi in Białowieża National Park in 2001

\begin{tabular}{ccccc}
\hline Snails & Examined & Infected & \% & Intensity \\
\hline $\begin{array}{c}\text { Succinea } \\
\text { putris }\end{array}$ & 1393 & 159 & 11.4 & $1-202$ \\
$\begin{array}{c}\text { Bradybaena } \\
\text { fruticum }\end{array}$ & 433 & 33 & 7.6 & $1-242$ \\
$\begin{array}{c}\text { Perforatella } \\
\text { bidens }\end{array}$ & 87 & 18 & 20.6 & $1-23$ \\
$\begin{array}{c}\text { Zonitoides } \\
\text { nitidus } \\
\text { Arion }\end{array}$ & 41 & 6 & 14.2 & 1 \\
$\begin{array}{c}\text { subfuscus } \\
\text { Vitrina } \\
\text { pellucida } \\
\begin{array}{c}\text { Trichia } \\
\text { hispida }\end{array}\end{array}$ & 7 & - & - & - \\
Limax \\
cinereo-niger
\end{tabular}

Table 4. Infection of snails with larvae of Elaphostrongylus cervi in Białowieża National Park in 2002

\begin{tabular}{ccccc}
\hline Snails & Examined & Infected & \% & Intensity \\
\hline $\begin{array}{c}\text { Succinea } \\
\text { putris } \\
\begin{array}{c}\text { Zonitoides } \\
\text { nitidus }\end{array}\end{array}$ & 158 & 2 & 1.27 & $1-3$ \\
$\begin{array}{c}\text { Bradybaena } \\
\text { fruticum }\end{array}$ & 24 & - & - & - \\
$\begin{array}{c}\text { Perforatella } \\
\text { bidens }\end{array}$ & 21 & - & - & - \\
$\begin{array}{c}\text { Laciniaria sp } \\
\text { Limax } \\
\text { cinereo-niger }\end{array}$ & 3 & - & - & - \\
\hline total & 1 & - & - & - \\
\hline
\end{tabular}

prevalence of infection in these species was $11.4 \%, 14.2$ $\%$ and $7.6 \%$ respectively.

The highest intensity of infection - 242 larvae was found in B. fruticum, and little lower - 202 in S. putris. In two other species intensity varied from 1 to 23 larvae.

In the years 2000, 2002, 2003 and 2004 examined snails were collected in September and October, and because of it samples from separate years were not numerous and not exceeded some hundreds snails. In the autumn months

Table 5. Infection of snails with larvae of Elaphostrongylus cervi in Białowieża National Park in 2003

\begin{tabular}{ccccc}
\hline Snails & Examined & Infected & \% & Intensity \\
\hline $\begin{array}{c}\text { Succinea } \\
\text { putris }\end{array}$ & 327 & 18 & 5.7 & $1-21$ \\
$\begin{array}{c}\text { Bradybaena } \\
\text { fruticum }\end{array}$ & 277 & 6 & 2.17 & $1-5$ \\
$\begin{array}{c}\text { Perforatella } \\
\text { bidens }\end{array}$ & 38 & 1 & 2.7 & 2 \\
$\begin{array}{c}\text { Zonitoides } \\
\text { nitidus }\end{array}$ & 2 & - & - & - \\
$\begin{array}{c}\text { Cochlicopa } \\
\text { lubrica }\end{array}$ & 6 & - & - & - \\
\hline total & $\mathbf{6 5 0}$ & $\mathbf{2 5}$ & $\mathbf{3 . 8 5}$ & \\
\hline
\end{tabular}

number of collected snails decreased significantly and it caused of their drying the summer heats, and by high mortality of infected specimens. It could influence on found then low prevalence and intensity of infection. Only snails examineted in 2001 were numerous (1964 specimens) and were collected also in summer months (from June to October). It allowed us to establish seasonal dynamics of invasion with larvae E. cervi in three most important species of snails. It has been determinate that from June to August the percentage of snails $S$. putris infected with $E$. cervi larvae had been on constant level and in September and October decreased. Snails B. fruticum the highest prevalance of invasion showed on July and later intensity successively decreased. However in case of $P$. bidentata prevalence of infection of $E$. cervi larvae was the lowest in August, and then raised up to the highest value in October. The last of mentioned species lives in forest litter, goes on plants only some centimeters up and it is very resistant on environmental conditions, in it drying. It makes that these snails can be infected during all vegetation season. 
Table 6. Infection of snails with larvae of Elaphostrongylus cervi in Białowieża National Park in 2004

\begin{tabular}{ccccc}
\hline Snails & Examined & Infected & \% & Intensity \\
\hline $\begin{array}{c}\text { Bradybaena } \\
\text { fruticum }\end{array}$ & 162 & - & - & \\
Succinea putris & 105 & 3 & 2.86 & $1-15$ \\
Valonia costata & 26 & - & - & - \\
Cochlicopa & 15 & - & - & - \\
lubrica & & & & \\
Limax sp. & 9 & - & - & - \\
Zonitoides & 6 & - & - & - \\
nitidus & & & & - \\
Perforatella & 3 & - & - & - \\
bidens & & & & - \\
Clausilia pumila & 3 & - & - & - \\
Arion subfuscus & 1 & - & - & \\
\hline total & $\mathbf{3 3 0}$ & $\mathbf{3}$ & $\mathbf{0 . 9}$ &
\end{tabular}

\section{Discusion}

Earlier investigations of other authors in Białowieża Forest showed that from 6 examined snail's species infection of $E$. cervi larvae have been found only in 5 . The highest infection was observed was in S. putris $-27 \%$. Prevalence of infection in remaining species was lower and reached in B. fruticum $8.3 \%$, P. bidentata $17.3 \%$, A. subfuscus $12.5 \%$ and $Z$. nitidus $9 \%$. The highest intensity extending 557 larvae was found also in $S$. putris (Demiaszkiewicz, 1987a). Observed prevalence and intensity of invasion in $S$. putris and $B$. fruticum was much higher than in presented investigation. It was caused by collecting of snails in closed yard for deer in the Show Reserve. Afterwards Misiewicz and Demiaszkiewicz (1994) in experimental hunting grounds of Forest Research Institute in Warmińsko-Mazurskie (Iława) and Śląskie (Pszczyna) voivodeships have been examined 5 species of snails: $A$. subfuscus, B. fruticum, Cepaea nemoralis, S. putris and $Z$. nitidus. The highest prevalence of infection of larvae $E$. cervi in Iława forest inspectorate was recorded in $S$. putris $-6.3 \%$ and in Pszczyna forest inspectorate $7.4 \%$ in this
Table 7. Spontaneus infection of snails with larvae of E. cervi in Białowieża National Park in 2000 - 2004

\begin{tabular}{|c|c|c|c|c|}
\hline Snails & Examined & Infected & $\%$ & Intensity \\
\hline $\begin{array}{l}\text { Succinea } \\
\text { putris }\end{array}$ & 2240 & 194 & 8.7 & $1-202$ \\
\hline $\begin{array}{l}\text { Bradybaena } \\
\text { fruticum }\end{array}$ & 993 & 42 & 4.2 & $1-242$ \\
\hline $\begin{array}{c}\text { Perforatella } \\
\text { bidens }\end{array}$ & 166 & 20 & 12.04 & $1-23$ \\
\hline $\begin{array}{l}\text { Zonitoides } \\
\text { nitidus }\end{array}$ & 97 & 6 & 6.2 & 1 \\
\hline $\begin{array}{l}\text { Valonia } \\
\text { costata }\end{array}$ & 26 & - & & \\
\hline $\begin{array}{c}\text { Cochlicopa } \\
\text { lubrica }\end{array}$ & 21 & - & & \\
\hline Limax sp. & 9 & - & & \\
\hline $\begin{array}{c}\text { Arion } \\
\text { subfuscus }\end{array}$ & 8 & - & & \\
\hline $\begin{array}{l}\text { Clausilia } \\
\text { pumila }\end{array}$ & 3 & - & & \\
\hline Laciniaria $s p$ & 3 & - & & \\
\hline $\begin{array}{c}\text { Limax } \\
\text { cinereo-niger }\end{array}$ & 2 & - & & \\
\hline $\begin{array}{l}\text { Trichia } \\
\text { hispida }\end{array}$ & 2 & - & & \\
\hline $\begin{array}{c}\text { Vitrina } \\
\text { pellucida }\end{array}$ & 2 & - & & \\
\hline total & 3572 & 262 & 7.3 & \\
\hline
\end{tabular}

same species. The highest intensity extending 150 larvae has been noted also in $S$. putris. In remaining species of snails infection with the larvae of $E$. cervi was found only in one case in Pszczyna forest inspectorate in $Z$. nitidus - one larva. Another research conducted by Demiaszkiewicz and Dróżdż (1997) showed prevalence of invasion of Protostrongylidae in deer farm in Kosewo Górne. Snails collected in fenced yards belonged to 4 species: S. putris, Z. nitidus, Zenobiella rubiginosa, Arion

Table 8. Dynamic of infection of most common snails with Elaphostrongylus cervi larvae in 2001

\begin{tabular}{|c|c|c|c|c|c|c|c|c|c|c|c|c|}
\hline \multirow{2}{*}{ Month - } & \multicolumn{4}{|c|}{ Succinea putris } & \multicolumn{4}{|c|}{ Bradybaena fruticum } & \multicolumn{4}{|c|}{ Perforatella bidens } \\
\hline & examined & infected & $\%$ & range & examined & infected & $\%$ & range & examined & infected & $\%$ & range \\
\hline VI & 350 & 45 & 12.8 & $1-202$ & 143 & 7 & 4.9 & $1-73$ & 12 & 3 & 25.0 & $1-23$ \\
\hline VII & 371 & 37 & 10.0 & $1-87$ & 119 & 16 & 13.4 & $1-242$ & 29 & 6 & 20.7 & $1-23$ \\
\hline VIII & 288 & 40 & 13.8 & $1-83$ & 80 & 7 & 8.8 & $1-35$ & 26 & 3 & 11.5 & $1-4$ \\
\hline IX & 245 & 29 & 11.8 & $1-35$ & 60 & 2 & 3.3 & $1-3$ & 16 & 3 & 18.7 & 1 \\
\hline $\mathbf{X}$ & 139 & 9 & 6.5 & $1-14$ & 31 & 1 & 3.2 & 6 & 4 & 3 & 75.0 & $1-5$ \\
\hline
\end{tabular}


circumscriptus. From them only $S$. putris was infected with larvae of Protostrongylidae. In first year prevalence of invasion of larvae E. cervi was $41 \%$ and next very dry year only $23 \%$. The highest intensity of infection reached 105 larvae. High prevalence of invasion in presented examinations was caused by high concentration of animals in the yards. We found more species of snails than cited authors, similar to Feliksiak (1935), who noted in Białowieża Forest from 16 to 33 species according to different types of crops. Big part of noted by this author species are the snails living in litter.

Present examinations showed that except $P$. bidens snails living in litter don't play any important role in distribution of invasion of $E$. cervi.

Found in our investigations prevalence of invasion $S$. putris with larvae E. cervi was much lower than presented by foreign authors (Ljubimow, 1959; Panin, 1964; Hale, 1980), and in Poland from Kosewo (Demiaszkiewicz \& Dróżdż, 1997) and Białowieża (Demiaszkiewicz, 1987a). According to Panin (1964) in Ałtaj the highest prevalence of invasion E. cervi occurred in Zenobiella nordenskioldi was $23.7 \%$. However Hale (1980) in Austria observed that the most infected species was B. fruticum $-21.7 \%$.

Noted in present examinations, infection of $S$. putris was similar to that presented by Misiewicz and Demiaszkiewicz (1994) conducted also in open hunting area. In farm conditions, there is higher concentration of larvae on small area.

In presented research were defined species of terrestrial snails which are the hosts of $E$. cervi in spontaneous invasion. There are: S. putris, B. fruticum, P. bidentata and $Z$. nitidus. Our work has showed that these species play the most important role in spreading of invasion of E. cervi in Białowieża Forest. For the first time the highest prevalence of spontaneous infection has been found in $P$. bidentata. Till now as the most infected species of snail always has been noted $S$. putris.

\section{References}

DemiaszKiewicz, A. W. (1987a): Some aspects of epizootiology of elaphostrongylosis in Białowieża Forest. Medycyna Wet., 43: 208 - 211 (In Polish)

DEMIASZKIEWICZ, A. W. (1987b): The species composition and extensiveness of protostrongylid nematods invasion in cervids on selected hunting grounds. Wiad. parazyt., 33: 57 - 62 (In Polish)

DemiaszKiewicz, A. W., DróżDŻ, J. (1997): Occurrence of larvae of protostrongylidae family in terrestial snails on the area of deer farm in Kosewo. Wiad. parazyt., 43: 431 434 (In Polish)

FELIKSIAK, S. (1935): Mollusca in bison reservae in Białowieża Forest. Inst. Bad. Lasów Państw., 10, 19 - 28 (In Polish)

HALE, J. (1980): Zur Entwicklung von Elaphostrongylus cervi Cameron 1931 in Zwischenwirt. Prakt.Tierarzt., 61, 34.

LJUBIMOW, M. P. (1959): News in epizootiology, profilactics and therapy of elaphostrongylosis of pants deer. In Sbornik statej po pantovomu olenovodstvu. Gorno-Altajsk. Knizn. Izd.: 164 - 214 (In Russian)

MisiewiCz J., DemiaszKIEWICZ, A. W. (1994): Occurrence of larvae of protostrongylidae family in terrestial snails in the wods of Olsztyn and silesian districts. Wiad. parazyt., 40: 167 - 172 (In Polish)

PANIN, V. JA. (1964): Importance of terrestials snails in dispersion of elaphostrongylosis of pants deers. Parazity Selsko-chozjajstvennych Životnych Kazachstana, Gelminty 3: 79 - 83 (In Russian) 